\title{
In the COVID-19 Pandemic Living with a Stoma and Being a Stoma Nurse
}

\section{COVID-19 Pandemisinde Stomayla Yaşamak ve Stoma Hemşiresi Olmak}

\author{
(1) Fatma Vural1', (1) Nazife Gamze Özer Özlü2 \\ ${ }^{1}$ Department of Surgical Diseases Nursing, İzmir, Turkey \\ 2Dokuz Eylül University Institue of Helath Sciences, pHD Student, Dokuz Eylül University Faculty of Nursing, Deparment of Surgical Diseases \\ Nursing, İzmir, Turkey
}

\section{HII\|I\|I ABSTRACT}

Stoma is created for reasons such as cancer, inflammatory bowel diseases and trauma to increase the quality of life of patients and to correct the underlying pathological condition. However, stoma causes major changes in patients' later life after opening. Patients take a great deal of time to adapt to the stoma and they need stoma therapy nurses. Stoma nurses, on the other hand, are responsible for the processes of diagnosis, treatment, and care services for these people, regardless of their conditions. During the coronavirus disease-19 (COVID-19) pandemic period, the responsibilities of stoma nurses continue to increase. Because of the pandemic conditions, the need of individuals with stoma for nurses increases more and it becomes difficult to reach nurses. This review was written to address the care of individuals with stoma and the issues that stoma nurses should pay attention during the pandemic period. The review was discussed in two parts: The individual with stoma and the stomatherapy nurse in the COVID-19 pandemic. As a result, individuals with stoma in the COVID-19 pandemic should stay at home as much as possible. When he/she needs to go to the hospital, he/she should contact the stoma nurse. During this period, stoma nurses should carry their daily work to online platforms. They should support individuals with stoma using phone, e-mail, and telehealth applications.

Keywords: Stoma individual, stomatherapy nurse, COVID-19 pandemic

\section{||l||l||| ÖZ}

Stoma; kanser, enflamatuvar bağırsak hastalıkları ve travma gibi nedenlerle hastaların yaşam kalitesini artırmak ve alttaki yatan patolojik durumu düzeltmek amacıyla açılmaktadır. Fakat stoma, açıldıktan sonra hastaların sonraki yaşamlarında büyük değişiklikler yapmasına neden olmaktadır. Hastaların stomaya uyum sağlaması büyük bir zaman almakta ve stoma terapi hemşirelerine gereksinimleri bulunmaktadır. Stoma hemşireleri ise koşulları ne olur olsun bu kişilere yönelik tanı, tedavi ve bakım hizmetlerinin etkin bir şekilde yerine getirilmesinden sorumludur. Koronavirüs hastalığı-19 (COVID-19) pandemisi döneminde de stoma hemşirelerinin sorumlulukları artarak devam etmektedir. Çünkü pandemi koşulları nedeniyle stomalı bireylerin hemşirelere olan gereksinimi daha fazla artmakta ve hemşirelere ulaşımı zorlaşmaktadır. Bu derleme pandemi döneminde stomalı bireylerin bakımı ve stoma hemşirelerinin dikkat etmesi gereken konuları belirtmek amacıyla yazıldı. Derleme, COVID-19 pandemisinde stomalı birey ve stomaterapi hemşiresi olmak üzere iki bölüm üzerinden ele alındı. Sonuç olarak, COVID-19 pandemisinde stomalı olan bireyler mümkün olduğu kadar evde kalmalıdır. Hastaneye gitmesi gerektiği durumlarda stoma hemşiresi ile iletişime geçmelidir. Bu dönemde stoma hemşireleri ise günlük olarak yapması gereken işlerini çevrimiçi platformlara taşımalıdır. Stomalı bireylere telefon, e-posta ve telesağlık uygulamalarını kullanarak destek vermelidir.

Anahtar Kelimeler: Stomalı birey, stomaterapi hemşiresi, COVID-19 pandemisi

\section{Introduction}

Stoma creation due to reasons such as colorectal cancers, ulcerative colitis, Crohn's disease, diverticular diseases, imperforate anus, traumas, intestinal obstructions, familial polyposis and congenital abnormalities greatly affects the lives of individuals. Because stoma requires individuals to change their life habits besides changes in body integrity and intestinal discharge. ${ }^{1,2}$ Although stoma seems to negatively

Address for Correspondence/Yazışma Adresi: Nazife Gamze Özer Özlü, 
affect the lives of individuals at first glance, the purpose of stoma is to prolong the life of people, to maket hem return to healthy and productive life, to increase the quality of life, and to correct the underlying pathological condition. ${ }^{3,4}$ It may take some time for individuals to realize the purpose of a stoma and adapt to it. Therefore, stoma nurses and other health professionals are needed to accelerate the adaptation process to the stoma. ${ }^{1,3,5}$ Due to the ongoing needs of individuals with stoma throughout their lives, communication with the stoma nurse continues. The stoma nurse, on the other hand, is responsible for the processes of diagnosis, treatment and care services for people with stoma, wound, incontinence and fistula problems, regardless of their conditions. ${ }^{6}$

Due to coronavirus disease-19 (COVID-19), which emerged on December 1, 2019 in Wuhan, the capital of the Hubei region of China and was declared a pandemic by the World Health Organization (WHO) on March 11, 2020, approximately $1,038,534$ people died so far, and as of October 5, 2020, 8,498 people died in our country. ${ }^{7,8}$ All health professionals and nurses caring for the patient were at the forefront in controlling the COVID-19 pandemic that affected the world. ${ }^{9,10}$ Stoma nurses also worked in emergency and pandemic services like other nurses during the pandemic period. They also continued to provide services for individuals with stoma.

The pandemic has caused many adverse events on the global health system..$^{10,11}$ The COVID-19 pandemic has potentially devastating effects for patients without COVID-19 due to its burden on the health system. Even in the normal lives of individuals, the presence of stoma has a great effect on the quality of life, while the need of these individuals for a nurse increases during the COVID-19 pandemic period. ${ }^{12}$ In this period, individuals with stoma represent a neglected group. Because, during the pandemic period, reducing the number of people admitting to the hospital to prevent in-hospital contamination, canceling elective surgeries in surgical clinics and employing health professionals in pandemic wards with insufficient medical resources made it difficult for individuals with stoma to reach stoma nurses. ${ }^{10,11,12}$

Many recommendations, guidelines and reviews on surgical and endoscopic applications in the COVID-19 pandemic have been published, and none of them has focused on individuals with stoma and stoma nurses. This review was written to address the care of individuals with stoma in the COVID-19 pandemic and the issues that stoma nurses should pay attention to. The review was evaluated in two parts: The individual with stoma and the stoma nurse during the pandemic period (Figure 1).

\section{Being an Individual with Stoma in the COVID-19 Pandemic}

In the COVID-19 pandemic, patients who show severe signs and symptoms of disease and have a poor prognosis are the patients in the fourth group. This group, that has a poor prognosis, represents 5\% of all patients and does not show signs and symptoms in the first five days. In the following days, they begin to present with severe symptoms and signs and require intensive care. Of the patients in this group 50\% result in death. ${ }^{9}$ The patients in this group are generally people over the age of 60-65 with chronic diseases such as cardiovascular disease, diabetes, obesity, chronic respiratory failure, cancer or immunodeficiency. ${ }^{13}$

Colorectal cancers that cause creating a stoma are ranked third worldwide in terms of mortality and morbidity. ${ }^{14}$ In our country, colorectal cancer is the third most common cancer type in both women and men. ${ }^{15}$ Most colorectal cancers occur in people over the age of 50 and the average age in men is 68 and the average age in women is 72 . It is 63 years for both men and women in rectal cancers. ${ }^{16}$ Therefore, individuals with stoma during the pandemic period have a higher risk of developing severe diseases, because individuals with stoma are generally elderly individuals with chronic disease. During this period, individuals with stoma are recommended to consult primary health care services in the assessment of risk factors for COVID-19. Stool and urine should be evaluated in terms of COVID-19 transmission. ${ }^{13}$ Recent studies have found that the virus remains in stool samples longer than in nasopharyngeal swab samples. ${ }^{17}$

Care guidelines should be created for individuals with stoma during the pandemic period. By following the established guidelines, treatment should be provided in a hospital that does not accept COVID-19 patients or in hospitals where patients with positive and negative COVID-19 are clearly distinguished. All individuals with stoma should be considered positive until proven otherwise. ${ }^{11}$ During the pandemic period, individuals with stoma should be evaluated in two ways: Inpatient and outpatient.

\section{Patients with Stoma in Hospital}

In the COVID-19 pandemic, it is recommended to open a stoma instead of the primary anastomosis to reduce the complication rate in general surgery services. ${ }^{10,11}$ During the pandemic period, the stoma place should be marked by the stoma nurse before the stoma is created. For this reason, both the stoma patient and their family should be educated and supported. ${ }^{12}$ Patients should wear a surgical mask and maintain hand hygiene during their stay in the hospital due to stoma creation. During stay in the hospital, the patient should avoid any personal contact with other patients and maintain physical distance measures. Disposable products/ accessories should be used and disposed of in special 


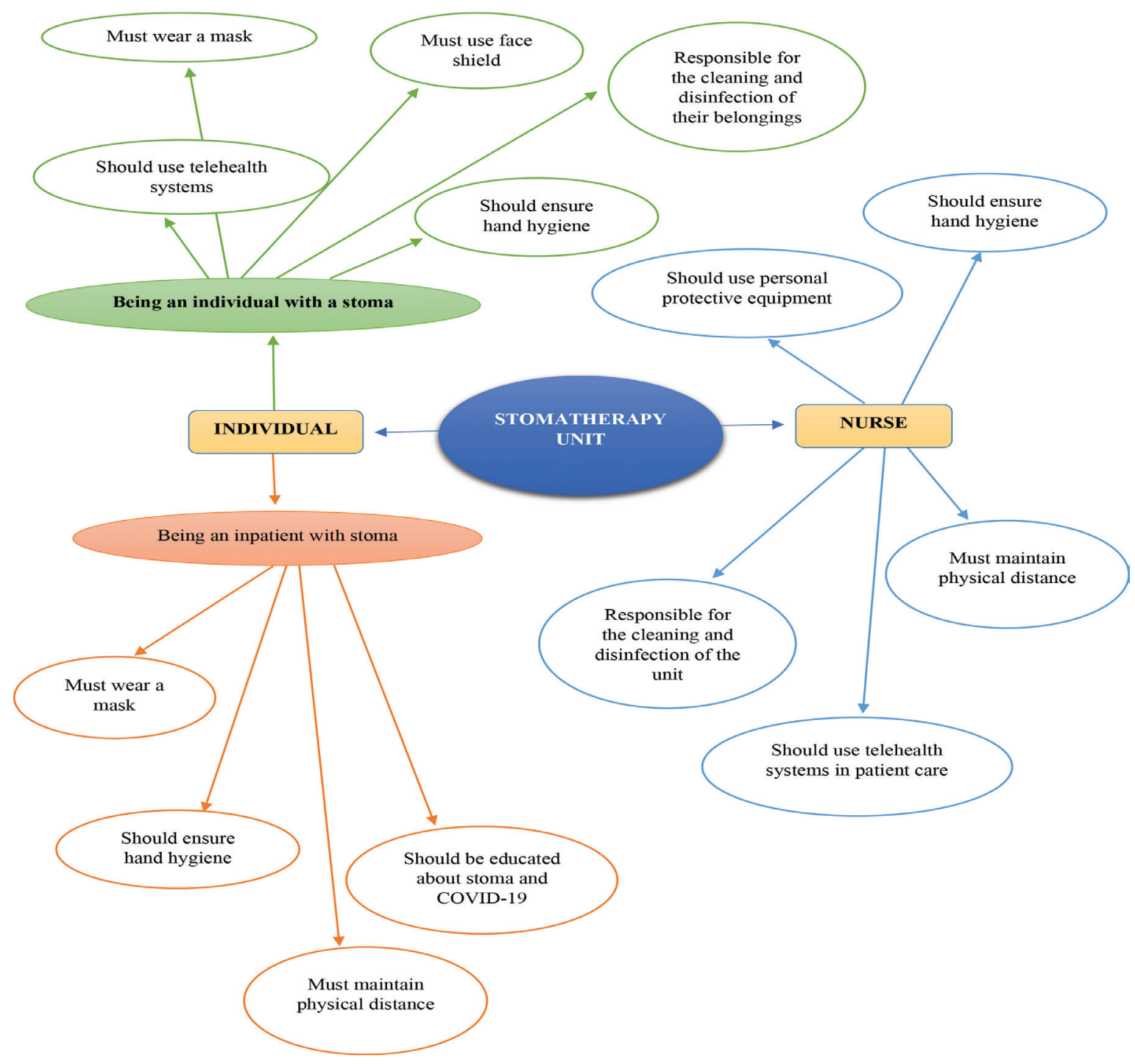

Figure 1. Being a stoma individual or a stoma nurse in the COVID-19 pandemic

infectious waste bins. ${ }^{11}$ When the individual with a stoma is discharged, his/her room must be thoroughly cleaned. On discharge, individuals should be informed to minimize the risk of COVID-19 transmission and to manage their home conditions. ${ }^{13}$ These informations include stoma management (stoma care, stoma products, supply of products, peristomal skin, intestinal gas, odor, constipation and diarrhea), stoma complications (describing situations requiring medical assistance or re-hospitalization) and living with stoma (personal cleaning, bathing or showering, return to work, clothing, nutrition and diet, traveling, sexual activities, stress management and worship). ${ }^{19,20}$ Apart from these issues, information should be given about home cleaning and disinfection (cleaning of the surface, electronic devices and laundry), food and garbage in the pandemic period. ${ }^{21}$ During the pandemic period, stoma care training may be somewhat lacking than it is under normal conditions. ${ }^{22}$ Therefore, after the stoma patient is discharged, the patient should be supported with home health care support and digital applications (telephone, mobile systems, application, video conferences).

\section{Outpatients with Stoma}

Elective patients should not be admitted to the stomatherapy unit during the pandemic period. Individuals who are planned to come to the stomatherapy unit should be called by phone for triage. ${ }^{11}$ The last 14 days of the individuals who are planned to come to the stomatherapy unit should be 
questioned in terms of COVID-19. Individuals with stoma should wear a face shield and mask before and after the visit, and should pay attention to hand hygiene. The individual with a stoma should be admitted to the stomatherapy unit alone and his/her body temperature should be measured. Individuals with stoma should be advised to wipe the items and surfaces they use with a cloth moistened with alcohol or bleach-based products. If possible, they should use a different bathroom than other family members and their underwear should be washed separately from those in the house. ${ }^{13}$

For individuals who do not come to the stomatherapy unit, telehealth (voice, image, speech and video and information transfer with tools such as telephone, computer, interactive television) should be applied. In a study in Italy during the COVID-19 pandemic, it was revealed that individuals with stoma who received telehealth applications on stoma care issues were satisfied. ${ }^{13}$ Individuals with stoma who cannot be managed with telehealth can be visited at home to reduce hospital visits. ${ }^{11}$ With all these practices, physical and psychosocial problems experienced by individuals with stoma should be tried to be minimized.

\section{Being a Stoma Nurse in the COVID-19 Pandemic}

During the pandemic period, stoma nurses should work as private branch nurses in hospitals and should be present in stomatherapy units so that their care giving continues without interruption. Stomatherapy units should remain open throughout the pandemic and should only accept individuals whose condition is an emergency. If there is a COVID-19 positive individual among the individuals who are planned to come to the stomatherapy unit during the pandemic period, the stoma nurse is recommended to provide care to this patient after other patients. The stoma nurse should examine the patient's file with stoma in a safe place before providing care. The information that should be added to the file should be asked to the patient and recorded by the stoma nurse. Then the nurse should wear personal protective equipment (gown, medical mask/N95/FFP2 mask, goggles/face shield, gloves). Stoma care should be made with as little contact with the patient as possible. ${ }^{11,23}$ Due to pandemic, a specific area should be determined in the unit before caring for the individual with stoma. The nurse should disinfect the materials to be used and select a clean area to store the materials he/she needs. For the products he/she uses, the nurse should determine the dirty area and arrange a container to collect the dirty products. ${ }^{24}$ The nurse should prepare brochures for individuals with stoma and their families in line with all current information. Apart from the individual with stoma, the nurse should also give the stoma care to the patient's caregiver in accordance with the physical distance rules. ${ }^{11}$

Stoma nurses should use personal protective equipment and maintain hand hygiene to protect their health and prevent cross contamination. Stoma nurses are responsible for the daily cleaning of the stomatherapy units. Cleaning the unit should be done from the clean area to the dirty area. In floor and surface disinfection, 1/100 diluted bleach or chlorine tablets (according to the product recommendation) should be used in areas contaminated with patients. Liquid soap and paper towels should be kept in the toilet of the unit and if there is a hand dryer, it should not be operated..$^{25}$ Good ventilation of the units should be provided. The windows should be left open for at least 15 minutes after the care of each stoma. ${ }^{26}$ Ventilation systems that take fresh air from outside should be installed for stomatherapy units within hospital facilities. In these systems equipped with specific motors and fans, two ventilation systems must be active to ensure air flow. Hall type air conditioners and ventilators should not be used. ${ }^{11,25}$

Except for non-emergency situations, the stoma nurse should remotely monitor issues such as tracking products, accessories, and prescriptions/reports and should provide consultancy service. For this, he/she can use e-mail, phone or digital applications. During the pandemic period, direct care for the patient with stoma decreases and consultations over the phone increase. Individuals can take photos and send them to their nurses when they have problems with their stoma. ${ }^{27}$ Online support group initiatives in digital applications can be made to increase the compliance of the patient with stoma. The online support group ensures that individuals with stoma can talk to each other, share their experiences and feelings, advise and guide each other via the internet. ${ }^{3}$ Online support groups can be made through associations and organizations related to stoma, forum sites, instagram and facebook. ${ }^{3,5}$ While providing these supports, the patient's primary caregiver should also be included. Thus, patient's compliance with digital applications can develop faster. ${ }^{5}$ In this period, ostomy product companies should also assist stoma nurses. In cases where the patient with a stoma cannot be adapted despite all the attempts made, the stoma nurse can go home visits at infrequent intervals by using personal protective equipment. However, during home visits, the institution may experience difficulties caused by the physical environment and the individual or their caregivers. ${ }^{28}$ Therefore, although telehealth application does not completely solve the problems of individuals with stoma, it reduces the workload of nurses as it reduces home visits. ${ }^{29}$ In addition, telehealth applications reduce the use of personal protective equipments and viral exposure. ${ }^{30}$ 
Another issue that stoma nurses should pay attention to in all these digital and telehealth applications is ethical issues. Protecting the privacy and confidentiality of individuals is one of the most important ethical principles. Necessary measures should be taken against the risk of inappropriate disclosure of information from these databases containing personal data of individuals. Informed consent forms should be transferred to electronic media. Individuals should sign an informed consent form that offers confidentiality in line with legal policies. For the security of the data collected with telehealth, it is important to perform two-factor authentication. Because, with hacking, this information can be passed on to third parties. Finally, although the internet infrastructure and electronic communication devices are on the rise, they may not be sufficient in some regions, especially in rural areas. For this reason, access to desired individuals can be difficult with these applications. Providing all individuals with access to digital and telehealth applications is also an ethical problem. Because everyone has the right to receive the same service. ${ }^{31}$

In addition, stoma nurses are also psychologically negatively affected by the difficulties they experience during the pandemic period. ${ }^{32}$ Among the difficulties experienced are risky working environments and working alone. ${ }^{33}$ In the forums organized for stoma nurses in the world, nurses stated that the virus lived longer in the stool and somatherapy units were at risk, that they did not know how to protect themselves because stomatherapy units were closed places, that it was difficult to face an invisible enemy, that they went home anxiously, that the number of patients decreased significantly due to the increase in telephone consultations, and that working alone in a quiet place and eating alone were boring, and that they missed close contact with their colleagues and patients. ${ }^{27,34}$

\section{Conclusion}

Patients with stoma during the COVID-19 pandemic should stay at home as much as possible. In order not to be infected, patients should be very careful even indoors. Before going to the hospital, the patient should contact the stomatherapy nurse by phone, e-mail or digital applications for problems with stoma. In cases where the patient needs to go to the hospital in an emergency, he/she should call the stoma nurse by phone. In cases where he/she must go to the hospital, he/ she should go using a mask and face shield, even if he/she does not have signs and symptoms of COVID-19.

Stoma therapy nurses should not accept individuals with stoma in the stomatherapy unit during the pandemic period, except for emergencies. For patients who need urgent stoma creation, stoma site marking should be made using personal protective equipment. The stoma nurse should carry the daily work he/she does to digital platform. Individuals with stoma should be contacted daily by phone or e-mail. The stoma nurse is responsible for the cleaning of the stomatherapy unit. Throughout the pandemic, stoma nurses should both protect their health and serve individuals with stoma as much as possible.

Peer-review: Internally and externally peer reviewed.

\section{Authorship Contributions}

Consept: F.V., N.G.Ö.Ö., Design: F.V., N.G.Ö.Ö., Analysis or Interpretation: F.V., N.G.Ö.Ö., Literature Search: F.V., N.G.Ö.Ö., Writing: F.V., N.G.Ö.Ö.

Conflict of Interest: No conflict of interest was declared by the authors.

Financial Disclosure: The authors declared that this study received no financial support.

\section{References}

1. Akıl Y, Taylan S. Bağırsak stomalı hastaların stomaya uyumlarını etkileyen faktörler: İlişkisel çalışma. Cukurova Med J 2020;45:428-438.

2. Taylan S, Akıl Y, Cihan R, Arslan S. Stoma torbası deneyiminin hemşirelerin farkındalıkları üzerine etkisi. Journal of Human Sciences 2017;14:22082218.

3. Sayar S, Vural F. Stomalı bireylerde destek grup girişimi yapılmalı mı? Turk J Colorectal Dis 2019;29:1-5.

4. Duluklu B, Şenol Çelik S. Kolostomisi olan bireylerde yaşam kalitesi: Sorunlar ve hemşirelik girișimleri. Hacettepe Üniversitesi Hemşirelik Fakültesi Dergisi 2019;6:111-119.

5. Bağrıaçık Altıntaș S, Vural F. Kolorektal kanserli hastalarda web tabanlı eğitim yapılmalı mı? Turk J Colorectal Dis 2018;28:1-8.

6. Hemşirelik Yönetmeliği. https://www.mevzuat.gov.tr/mevzuatmetin/ yonetmelik/7.5.13830-ek-2\%20ve\%203.html Erişim tarihi: 02.10.2020.

7. World Health Organization (WHO) Coronavirus disease (COVID-19) Dashboard. https://covid19.who.int/ Erişim tarihi: 02.10.2020.

8. T.C. Sağlık Bakanlığı COVID-19 Bilgilendirme Sayfası. https://covid19. saglik.gov.tr/ Erişim tarihi: 02.10.2020

9. Yörük Bal E, Çelik H. COVID-19 salgını ile mücadelede hemşirenin rolü. Turkiye Klinikleri J Nurs Sci 2020;12:300-304.

10. Şanlı D. COVID-19 pandemisinde cerrahi bakıma yönelik kanıta dayalı öneriler. İzmir Kâtip Çelebi Üniversitesi Sağlık Bilimleri Fakültesi Dergisi 2020;5:183-190

11. Pata F, Bondurri A, Ferrara F, Parini D, Rizzo G. Enteral stoma care during the COVID-19 pandemic: Practical advice. Colorectal Dis 2020;22:985992

12. D'Antonio D, Pizza F, Tropeano FP, De Palma G, Marvaso A, Luglio G. COVID-19 outbreak and stoma care on a minor island in Italy: Physically far, virtually near. SN Comprehensive Clinical Medicine 2020;2:13021305.

13. Maculotti D, Spena PR, Villa G. Position statement on care of ostomy patients during COVID-19 pandemic. Gastroenterol Nurs 2020;43:324326.

14. International Agency fo Research on Center (IARC) (2018, 28 Eylül). Colorectal cancer source: Globocan 2018. http://gco.iarc.fr/today/data/ factsheets/cancers/10_8_9-Colorectum-fact-sheet.pdf Erişim Tarihi: 02.10.2020. 
15. T.C. Sağlık Bakanlığı Sağlık İstatistikleri Yıllı̆̆ı 2018. https://dosyasb. saglik.gov.tr/Eklenti/36134,siy2018trpdf.pdf?0 Erişim Tarihi:02.10.2020.

16. American Society of Clinical Ongology. Colorectal cancer: risk factors and prevention. https://www.cancer.net/cancer-types/colorectalcancer/risk-factors-and-prevention\#: :text=Colorectal\%20cancer $\% 20$ can\%20occur\%20in,for\%20both\%20men\%20and\%20women Erişim Tarihi:02.10.2020.

17. Chen Y, Chen L, Deng Q, Zhang G, Wu K, Ni L, Yang Y, Liu B, Wang W, Wei C, Yang J, Ye G, Cheng Z. The presence of SARS-CoV-2 RNA in feces of COVID-19 patients. J Med Virol 2020;92:833-840.

18. Öztürk D., Karadağ A. Stoma ve yara bakım hemşireliğinin tarihsel gelişim süreci: Türkiye örneği. Hemşirelikte Eğitim ve Araştırma Dergisi 2019;16:73-78.

19. Hooper J. Colostomy guide. United Ostomy Associations of America, 2017. www.ostomy.org Erişim tarihi: 26.09.2020.

20. Vural F, Sütsünbüloğlu E, Şelimen D. Literatür inceleme: Stomalı bireylere yönelik yayınların Türkiye profili. Turk J Colorectal Dis 2016;26:59-70.

21. Bilik Ö. Hasta ve yakınlarının eğitiminde COVID-19: Hemşireler ne anlatmal1? J Biotechnol and Strategic Health Res 2020;4:78-88

22. Skowron KB, Hurst RD, Umanskiy K, Hyman NH, Shogan BD. Caring for patients with rectal cancer during the COVID-19 pandemic. Journal of Gastrointestinal Surgery 2020;24:1698-1703.

23. Kamer E, Çolak T. COVID-19 ile enfekte bir hastasının operasyona ihtiyacı olduğunda ne yapmalıyız: Cerrahi öncesi, cerrahi sırası ve cerrahi sonrası rehberi. Turk J Colorectal Dis 2020;30:1-8.

24. Atos Breating- Speaking- Living. Stoma care during the COVID-19 pandemic. https://www.atosmedical.com.au/care-tips/stoma-care-duringthe-covid-19-pandemic/ Erişim Tarihi: 02.10.2020.

25. T.C. Sağllk Bakanlığı. COVID-19 pandemisinde normalleşme döneminde sağlık kurumlarında çalışma rehberi bilimsel danışma kurulu çalışma (1 Haziran 2020). https://ohsad.org/wp-content/uploads/2020/06/
COVID 19-PANDEMISINDE_NORMALLESME_DONEMINDE_ SAGLIK_KURUMLARINDA_CALISMA_REHBERI.pdf.pdf Erişim Tarihi: 02.10.2020.

26. T.C. Şehircilik ve Çevre Bakanlı̆̆ı. Koronavirüs hastalığı (COVID-19) virüsünün kamu binalarında yayılmasının önlemek için havalandırma ve klimasistemleri(hvac)sistemindealınmasigerekentedbirlerkılavuzu.https:// www.dosab.org.tr/dosyalar/dokumanlar/280420201634581FSDD6.pdf Erişim Tarihi:02.10.2020.

27. Eakin. How stoma nurses around the world are being impacted by and dealing with the COVID-19 pandemic. https://www.eakin.eu/stomanurses-covid-19/ Erişim Tarihi: 25.09.2020.

28. Yurtsever N, Yılmaz M. Evde bakım alanında çalışan hemşirelerin çalışma koşulları, yaşadıkları güçlükler ve eğitim gereksinimlerinin belirlenmesi. İzmir Kâtip Çelebi Üniversitesi Sağlık Bilimleri Fakültesi Dergisi 2016;1:1925.

29. Augestad KM, Sneve AM, Lindsetmo RO. Telemedicine in postoperative follow-up of STOMa PAtients: A randomized clinical trial (the STOMPA trial). Br J Surg 2020;107:509-518.

30. Mills EC, Savage E, Lieder J, Chiu ES. Telemedicine and the COVID-19 pandemic: Are we ready to go live? ADV Skın Wound Care 2020;33:1-8.

31. Özden F, Lembarki Y. The ethical necessities and principles in telerehabilitation. Journal of Health Services and Education 2020;3:35-37.

32. Sheehan LE. COVID experience. J Wound Ostomy Continence Nurs. 2020;47:311.

33. Tuncay FE., Koyuncu E., Özel \$̧. Pandemilerde sağlık çalışanlarının psikososyal sağlı̆ını etkileyen koruyucu ve risk faktörlerine ilişkin bir derleme. Ankara Med J 2020;:488-501.

34. StomaTips. Coronavirus: Stoma care in a global pandemic. https:// www.stomatips.com/features/article/coronavirus-stoma-care-in-a-globalpandemic Erişim Tarihi:02.10.2020. 